Фармацевтична технологія, біофармація, гомеопатія Pharmaceutical technology, biopharmacy, homeopathy

Рекомендована д. фрармац. наук, профр. Т. Г. Калинюком УДК 615.07:615.45

DOI 10.11603/2312-0967.2018.2.9013

\title{
ВИБІР КІЛЬКІСНОГО СКЛАДУ ДОПОМІЖНИХ РЕЧОВИН ПРИ СТВОРЕННІ ТАБЛЕТОК ЦЕОЛІТУ ПРИРОДНОГО (КЛІНОПТИЛОЛІТУ)
}

\author{
(C) В. Д. Рибачук, О. А. Рубан \\ Національний фрармацевтичний університет, Харків \\ v.d.rybachuk@gmail.com
}

\begin{abstract}
Мета роботи. Вивчити вплив кількостей допоміжних речовин на фрармако-технологічні властивості таблеток цеоліту природного (кліноптилоліту) та оптимізувати склад готової лікарської фрорми.

Матеріали і методи. Об'єкти досліджень - таблетки цеоліту природного середньої маси 0,55 г та діаметром 10 мм, отримані пресуванням із попередньою вологою грануляцією. У дослідженнях використовували цеоліт природний (кліноптилоліт) Сокирницького родовища (Закарпатська область, Україна). Для вибору срармацевтичних фракторів, які суттєво впливають на об'єкт дослідження, використовували дробний фракторний експеримент $2^{3} 3$ рівним дублюванням дослідів. Вивчено 3 кількісні фрактори, взаємозв'язок між фоакторами та фрармако-технологічними показниками таблеток виражали та інтерпретували за допомогою рівнянь регресії. У дослідах використовували сучасне обладнання. Для тестів користувалися методиками Державної фрармакопеї України.

Результати й обговорення. За отриманими даними встановлено, що на однорідність маси таблеток найбільшою мірою впливає концентрація зволожувача, на механічну стійкість до роздавлювання - концентрація наповнювача на стійкість до стирання - вміст суміші лактози моногідрату з МКЦ-101 та крохмалю картопляного, а на час розпадання - вміст крохмалю картопляного. За допомогою регресійного аналізу та додаткових досліджень за схемою «крутого сходження» встановлено оптимальний склад таблеток цеоліту природного (кліноптилоліту): цеоліту природного (кліноптилоліту) - 0,4 г; суміші лактози моногідрату з МКЦ-101 (1:1) - 0,085 г; крохмалю картопляного - 0,047 г; 7 \% клейстеру крохмального картопляного - 0,1 г (0,007 г сухого); кальцію стеарату 0,003 г.

Висновок. Проведено дослідження з підбору кількісного вмісту допоміжних речовин для отримання таблеток цеоліту природного пресуванням із попередньою вологою грануляцією та запропоновано оптимальний склад таблеток, властивості яких відповідають діючим вимогам ДФУ.
\end{abstract}

Ключові слова: цеоліт природний; кліноптилоліт; таблетки; допоміжні речовини; волога грануляція; кількісні фрактори.

Вступ. Еферентна терапія як метод елімінації токсичних продуктів із організму набуває все більшої популярності в різних галузях клінічної медицини. Серед усіх методів ефрерентної терапії ентеросорбція як метод неінвазивної детоксикації привертає все більше уваги і при адекватному використанні сприяє досягненню локального та системного позитивного ефекту. Видалення сполук, які негативно впливають на організм, таких як алергени, активні пероксиди, віруси, токсини, медіатори запалення, а також запобігання їх руху в системний кровоток, стимулює механізми резистентності організму, перешкоджає розвитку надлишкових запальних реакцій, покращує метаболізм $[1,2]$. Якість і економічність ентеросорбційної терапії визначається в першу чергу видом застосовуваного ентеросорбенту. Одними 3 перспективних джерел ентеросорбентів $є$ природні мінерали. Високий і стабільний інтерес до даної групи речовин зумовлений наявністю у них широкого спектра прямих і опосередкованих лікувально-профрілактичних ефек- тів, які досягаються за рахунок фрізико-хімічних властивостей, здатності зв'язувати і виводити з організму токсичні продукти [3-6]. Перспективною мінеральною сировиною для створення ентеросорбентів $€$ цеоліти природні [7, 8].

У попередніх дослідженнях із вибору оптимальних допоміжних речовин (ДР) для отримання таблеток цеоліту методом вологої грануляції ми встановили, що найкращі результати щодо фармако-технологічних показників таблеток цеоліту отримано при використанні лактози та мікрокристалічної целюлози (МКЦ-101) (наповнювач), 7 \% клейстеру картопляного крохмального (зв'язуючий розчин), мікрокристалічної целюлози (МКЦ-101) (розпушувач) та кальцію стеарату (антифррикційна речовина). Відомо, що особливу увагу при створенні таблеток приділяють кількісному складу ДР, які входять до композиції та забезпечують отримання продукту фрармакопейної якості.

Мета роботи - вивчення впливу кількостей допоміжних речовин на фрармако-технологічні властивості

ISSN 2312-0967. Фармацевтичний часопис. 2018. № 2 
таблеток цеоліту природного та оптимізація складу готової лікарської форми.

Матеріали і методи. Об'єктами досліджень слугували таблетки цеоліту природного середньою масою 0,55 г отримані пресуванням із попередньою вологою грануляцією. У дослідженнях використовували цеоліт природний (кліноптилоліт) Сокирницького родовища (Закарпатська область, Україна), властивості якого наведено в нашій попередній роботі [8]. Таблетки пресували на лабораторній таблетковій машині (Україна, Маріупольський завод технологічного обладнання), використовуючи матрицю діаметром 10 мм. При оптимізації складу таблеток було вивчено 3 кількісні фрактори. Перелік фракторів та їх рівнів наведено в таблиці 1. При складанні рецептури таблеток кількість кальцію стеарату на стадії опудрення гранул складала 1 \%. У дослідах використовували сучасне обладнання для визначення однорідності маси таблеток (ваги лабораторні RADWAG PS510/C/2, Польща), стійкості до стирання (прилад для визначення стирання Pharmatest D-63512 Hainburg, Німеччина), часу розпаду (Pharma Test PTWS 120S, Німеччина) та механічної міцності (прилад для визначення механічної міцності на стиск Pharmatest PTB 111 EP Hainburg, Німеччина). Для проведення зазначених тестів користувалися методиками Державної фрармакопеї України [9].

Для вибору фармацевтичних факторів, які суттєво впливають на об'єкт дослідження, використовували повний фракторний експеримент $2^{3} 3$ рівним дублю-
Фармацевтична технологія, біофармація, гомеопатія Pharmaceutical technology, biopharmacy, homeopathy

ванням дослідів. Планування експерименту здійснювали за алгоритмом, який наведено в монографрії «Математичне планування експерименту при проведенні наукових досліджень в срармації» [10]. Взаємозв'язок між вивченими кількісними фракторами та фрармако-технологічними показниками таблеток виражали та інтерпретували за допомогою рівнянь регресії. Адекватність моделей та статистичну значущість коефіцієнтів перевіряли за допомогою F-критерію. Побудовані рівняння вважали адекватними, коли $\mathrm{F}_{\text {експ. }}<\mathrm{F}_{\text {табл }}$.

Результати й обговорення. Матриця плану $2^{3}$ i результати досліджень наведено в таблиці 2. Всі отримані дисперсії були перевірені за величиною критерію Кохрена та виявилися однорідними.

Визначення зовнішнього вигляду проводили за візуальною оцінкою. Критерії оцінювання зовнішнього вигляду після пресування були наступними: оцінка 5 - поверхня блискуча, краї чіткі; оцінка 4 - поверхня матова, краї нерівні; оцінка 3 - поверхня матова, краї щерблені. При отриманні таблеток цеоліту їх зовнішній вигляд відповідав вимогам ДФУ, тому за цим відгуком $\left(\mathrm{y}_{1}\right)$ рівнянь регресії не наводимо.

Вплив досліджуваних фракторів на однорідність маси таблеток описується рівнянням регресії:

$$
\begin{gathered}
y_{2}=1,0062+0,0495 x_{1}-0,3987 x_{2}+0,0645 x_{3}+0,1029 x_{1} x_{2}- \\
0,1187 x_{1} x_{3}+0,1829 x_{1} x_{2} x_{3}
\end{gathered}
$$

У цьому та нижченаведених рівняннях регресії вказані тільки статистично значущі коефіцієнти. Згід-

Таблиця 1. Кількісні фрактори та їх рівні, які вивчали при оптимізації складу таблеток цеоліту природного

\begin{tabular}{|c|c|c|c|c|}
\hline \multirow[b]{2}{*}{ Фактор } & \multirow{2}{*}{$\begin{array}{l}\text { Інтервал } \\
\text { варіювання }\end{array}$} & \multicolumn{3}{|c|}{ Рівні фракторів } \\
\hline & & $\begin{array}{c}\text { нижній } \\
\ll-»\end{array}$ & $\begin{array}{l}\text { основний } \\
\text { «0» }\end{array}$ & $\begin{array}{c}\text { верхній } \\
\ll+»\end{array}$ \\
\hline $\begin{array}{l}\text { x - кількість наповнювача (суміш лактози та МКЦ-101 } \\
\text { у співвідношенні 1:1), \% від середньої маси таблетки }\end{array}$ & 5 & 5 & 10 & 15 \\
\hline $\begin{array}{lccc}x_{2}- & \text { концентрація } \\
\text { крохмального клейстера, } \% & \end{array}$ & 2 & 3 & 5 & 7 \\
\hline $\begin{array}{l}\text { x }- \text { кількість розпушувача крохмалю картопляного, \% } \\
\text { від середньої маси таблетки }\end{array}$ & 2 & 3 & 5 & 7 \\
\hline
\end{tabular}
(кліноптилоліт)

Таблиця 2. Матриця планування експерименту та результати дослідження

\begin{tabular}{|c|c|c|c|c|c|c|c|c|c|c|c|c|}
\hline № cepiï & $\mathrm{x}_{1}$ & $\mathrm{x}_{2}$ & $\mathrm{x}_{3}$ & $\mathrm{x}_{1} \mathrm{x}_{2}$ & $\mathrm{x}_{1} \mathrm{x}_{3}$ & $\mathrm{x}_{2} \mathrm{x}_{3}$ & $\mathrm{x}_{1} \mathrm{x}_{2} \mathrm{x}_{3}$ & $\mathrm{y}_{1}$ & $\mathrm{y}_{2}$ & $\mathrm{y}_{3}$ & $\mathrm{y}_{4}$ & $\mathrm{y}_{5}$ \\
\hline 1 & + & + & + & + & + & + & + & 5 & 0,87 & 102 & 0,23 & 1,31 \\
\hline 2 & - & + & + & - & - & + & - & 5 & 0,44 & 80 & 0,63 & 1,27 \\
\hline 3 & + & - & + & - & + & - & - & 5 & 1,13 & 76 & 0,45 & 1,13 \\
\hline 4 & - & - & + & + & - & - & + & 5 & 1,84 & 61 & 0,78 & 1,11 \\
\hline 5 & + & + & - & + & - & - & - & 5 & 0,64 & 87 & 0,33 & 2,53 \\
\hline 6 & - & + & - & - & + & - & + & 5 & 0,47 & 62 & 0,95 & 2,11 \\
\hline 7 & + & - & - & - & - & + & + & 5 & 1,58 & 78 & 1,07 & 2,33 \\
\hline 8 & - & - & - & + & + & + & - & 5 & 1,08 & 42 & 1,20 & 1,95 \\
\hline
\end{tabular}

Примітки: $y_{1}$ - зовнішній вигляд таблеток, бали; $y_{2}$ - однорідність маси таблеток, $\pm \% ; y_{3}-$ міцність таблеток, Н; $\mathrm{y}_{4}$ - стираність таблеток, \%; $\mathrm{y}_{5}-$ час розпадання таблеток, хв.

ISSN 2312-0967. Pharmaceutical review. 2018. № 2 
Фармацевтична технологія, біофармація, гомеопатія Pharmaceutical technology, biopharmacy, homeopathy

но 3 наведеним рівнянням, на значення досліджуваного показника впливають всі експериментальні фрактори, а значущими виявились сім коефіцієнтів. Більшою мірою однорідність залежить від концентрації зволожувача (фрактор $\mathrm{x}_{2}$ ), збільшення якої призводить до підвищення стабільності маси таблеток. Це може бути зумовлено зменшенням вмісту дрібної фрракції гранул та досягненням більшої однорідності їх розміру, що, безсумнівно, позначається на швидкості подачі таблеткової маси в матрицю таблеткової машини при пресуванні [11]. Збільшення значень інших фракторів як окремо, так і у взаємодії, навпаки, призводить до збільшення неоднорідності вивченого параметра. Слід також зазначити, що за даним показником всі експериментальні серії повністю відповідають вимогам ДФУ [9].

Взаємозв'язок між вивченими фракторами та механічною міцністю таблеток до роздавлювання описується рівнянням регресії:

$y_{3}=73,58+12,33 x_{1}+9,25 x_{2}+6,33 x_{3}-2,92 x_{1} x_{3}+2,25 x_{2} x_{3}$

Аналіз рівнянь регресії показує, що для даного показника значущими виявились шість коефіцієнтів. За величиною впливу на механічну міцність таблеток вивчені фрактори можна розташувати у такій послідовності: $x_{1}>x_{2}>x_{3}$. Згідно 3 рівнянням регресії, найбільший вплив на стійкість таблеток до роздавлювання має кількість наповнювача в їх складі, при цьому із збільшенням кількості суміші лактози моногідрату та МКЦ-101 механічна міцність таблеток збільшується. Збільшення механічної міцності також спостерігається при збільшенні концентрації зволожувача та розпушувача, однак сила впливу даних речовин менша. Слід також вказати на позитивний вплив на міцність взаємодії фракторів $\mathrm{x}_{2}$ та $\mathrm{x}_{3}$. Результатом взаємодії фракторів $\mathrm{x}_{1}$ та $\mathrm{x}_{3} \in$ незначне зменшення міцності таблеток, проте воно нівелюється впливом трьох інших фракторів.

Взаємозв'язок між вивченими фракторами та стиранням таблеток описується рівнянням регресії:

$$
\begin{gathered}
y_{4}=0,7054-0,1854 x_{1}-0,1712 x_{2}-0,1854 x_{3}- \\
0,0704 x_{1} x_{2}+0,0779 x_{2} x_{3}-0,0537 x_{1} x_{2} x_{3}
\end{gathered}
$$

Аналіз рівнянь регресії показує, що для даного показника значущими виявились сім коефіцієнтів. За величиною впливу на стирання таблеток вивчені фрактори можна розташувати в такій послідовності: $\mathrm{x}_{1}=\mathrm{x}_{3}>\mathrm{x}_{2}$. Найбільшою мірою стираність зменшується при збільшенні вмісту суміші лактози моногідрату 3 МКЦ-101 та крохмалю картопляного, яким незначно поступається вміст та концентрація зволожувача. Слід також підкреслити слабку взаємодію фракторів, ефект від якої майже у 3,4 раза менший порівняно 3 впливом кожного фрактора окремо. Вимогам ДФУ за показником стираності відповідають експериментальні серії № 1-6 [9].

Взаємозв'язок між вивченими фракторами та розпаданням таблеток описується рівнянням регресії:

$\mathrm{y}_{5}=1,767+0,1095 \mathrm{x}_{1}+0,0854_{2}-0,4629 \mathrm{x}_{3}-0,0921 \mathrm{x}_{1} \mathrm{x}_{3}$

Аналіз рівняння регресії показав, що значущими виявились п'ять коефріцієнтів, а найбільшим чином на час розпадання таблеток впливає кількість розпушувача (фактор $\mathrm{x}_{3}$ ), збільшення вмісту якого призводить до суттєвого зменшення витраченого на розпадання часу. Ефрект даного фрактора також підсилюється взаємодією фракторів $x_{1} x_{3}$. Збільшення концентрації зволожувача (фрактор $x_{2}$ ) та вмісту наповнювача (фрактор $\mathrm{x}_{1}$ ) призводить до подовження часу розпадання. Слід зазначити, що за даним параметром всі експериментальні серії відповідають вимогам ДФУ [7].

Проведені дослідження показали, що в 6-ти із 8-ми серій дослідів отримали таблетки цеоліту природного, які повністю відповідали вимогам ДФУ за всіма технологічними показниками. Ми для більш точного визначення кількостей ДР провели додаткові дослідження за схемою «крутого сходження» до оптимуму. Враховуючи отримані данні, а також результати наших попередніх досліджень [12] значення $x_{2}$ на етапі крутого сходження ми вирішили стабілізувати на верхньому рівні. Щодо показників розпадання, ми вважали за доцільне програмування даного параметра в межах $(1,0-1,5 \pm 0,1)$ хв. Значне збільшення часу розпадання недоцільне 3 огляду на цільове призначення лікарської форми, а саме використання як ентеросорбенту, в тому числі для лікування отруєнь, що вимагає швидкої дії препарату. В даний діапазон добре вкладаються серії № 1-4, проте серія № 4 має меншу механічну міцність. Найкращі технологічні властивості продемонструвала серія № 1, яка мала максимальну механічну міцність, найменше стирання, проте час розпадання був дуже наближеним до верхньої межи обраного нами діапазону. Тому в якості точки старту для крутого сходження ми обрали верхній рівень для фракторів $\mathrm{x}_{1}$ та $\mathrm{x}_{3}$ рухаючись у бік збільшення вмісту речовин для зменшення часу розпадання. Крок для фракторів $x_{1}$ та $x_{3}$ зменшили та встановили на рівні 0,25 та 0,8 відповідно. Результати наведено в таблиці 3.

Таблиця 3. Круте сходження до оптимуму

\begin{tabular}{|c|c|c|c|c|c|c|c|c|}
\hline № досліду & $\mathrm{x}_{1}$ & $\mathrm{x}_{2}$ & $\mathrm{x}_{3}$ & $\mathrm{y}_{1}$ & $\mathrm{y}_{2}$ & $\mathrm{y}_{3}$ & $\mathrm{y}_{4}$ & $\mathrm{y}_{5}$ \\
\hline 1 & 15,25 & 7 & 7,8 & 5 & 0,85 & 107 & 0,21 & 1,31 \\
\hline 2 & 15,5 & 7 & 8,6 & 5 & 0,92 & 110 & 0,19 & 1,2 \\
\hline 3 & 15,75 & 7 & 9,4 & 5 & 0,98 & 103 & 0,28 & 1,05 \\
\hline 4 & 16 & 7 & 10,2 & 5 & 1,05 & 85 & 0,55 & 0,58 \\
\hline 5 & 16,25 & 7 & 11 & 5 & 1,23 & 61 & 0,67 & 0,42 \\
\hline
\end{tabular}

ISSN 2312-0967. Фармацевтичний часопис. 2018. № 2 
Фармацевтична технологія, біофармація, гомеопатія

Pharmaceutical technology, biopharmacy, homeopathy

Аналіз отриманих даних дозволяє зробити висновок, що найбільш оптимальним є склад використаний в досліді № 2, а підвищення вмісту зазначених речовин не приводить в подальшому до покращення технологічних показників, а час розпадання наближує до нижньої границі обраного нами проміжку. Таким чином, в результаті додаткових досліджень запропоновано оптимальний склад таблеток цеоліту природного (кліноптилоліту): цеоліту природного (кліноптилоліту) - 0,4 г; суміші лактози моногідрату 3 МКЦ-101 (1:1) - 0,085 г; крохмалю картопляного 0,047 г; 7 \% клейстеру крохмального картопляного 0,1 г (0,007 г сухого); кальцію стеарату - 0,003 г. Та-

блетки обраного кількісного складу відповідають всім діючим орармако-технологічним вимогам ДФУ [9].

Висновки. 1. Проведено дослідження 3 підбору кількісного вмісту допоміжних речовин для отримання таблеток цеоліту природного пресуванням із попередньою вологою грануляцією.

2. За допомогою регресійного аналізу встановлено оптимальний склад таблеток цеоліту природного (кліноптилоліту): цеоліту природного (кліноптилоліту) - 0,4 г; суміші лактози моногідрату з МКЦ-101 (1:1) - 0,085 г; крохмалю картопляного - 0,047 г; крохмального картопляного клейстеру $7 \%-0,1$ г (0,007 г сухого); стеарату кальцію - 0,003 г.

\title{
ВЫБОР КОЛИЧЕСТВЕННОГО СОСТАВА ВСПОМОГАТЕЛЬНЫХ ВЕЩЕСТВ ПРИ СОЗДАНИИ ТАБЛЕТОК ЦЕОЛИТА ПРИРОДНОГО (КЛИНОПТИЛОЛИТА)
}

\author{
В. Д. Рыбачук, Е. А. Рубан \\ Национальный фрармацевтический университет, Харьков \\ v.d.rybachuk@gmail.com
}

Цель работы. Изучить влияние количества вспомогательных веществ на фрармако-технологические свойства таблеток цеолита природного (клиноптилолита) и оптимизировать состав готовой лекарственной формы.

Материалы и методы. Объектами исследования служили таблетки цеолита природного средней массы 0,55 г и диаметром 10 мм, полученные прессованием с предварительной влажной грануляцией. В исследованиях использовался цеолит природный (клиноптилолит) Сокирницкого месторождения (Закарпатская область, Украина). Для выбора фрармацевтических фракторов, которые существенно влияют на объект исследования, использовали дробный фракторный эксперимент $2^{3}$ с равным дублированием опытов. Было изучено 3 количественных фрактора, взаимосвязь между фракторами и фрармако-технологическими показателями таблеток выражали и интерпретировали с помощью уравнений регрессии. В опытах использовали современное оборудование. Для тестов пользовались методиками Государственной фрармакопеи Украины.

Результаты и обсуждение. По полученным данным установлено, что на однородность массы таблеток в наибольшей степени влияет концентрация увлажнителя, на механическую устойчивость к раздавливанию концентрация наполнителя, на устойчивость к истиранию - содержание смеси лактозы моногидрата с МКЦ-101 и крахмала картофельного, а на распадаемость - содержание крахмала картофельного. С помощью регрессионного анализа и дополнительных исследований по схеме «крутого восхождения» установлен оптимальный состав таблеток цеолита природного (клиноптилолита): цеолита природного (клиноптилолита) - 0,7 г; смеси лактозы моногидрата с МКЦ-101 (1:1) - 0,085 г; крахмала картофрельного - 0,047 г, 7 \% крахмального картофельного клейстера - 0,1 г (0,007 г сухого вещества), кальция стеарата - 0,003 г.

Вывод. Проведены исследования по подбору количественного состава вспомогательных веществ для получения таблеток цеолита природного прессованием с предварительной влажной грануляцией и предложен оптимальный состав таблеток, свойства которых соответствуют действующим требованиям ГФУ.

Ключевые слова: цеолит природный; клиноптилолит; таблетки; вспомогательные вещества; влажная грануляция; количественные фракторы.

\section{SELECTION OF COMPOSITION OF EXCIPIENTS IN CREATION OF NATURAL ZEOLITE TABLETS (CLINOPTILOLITE)}

\author{
V. D. Rybachuk, O. A. Ruban \\ National University of Pharmacy, Kharkiv \\ v.d.rybachuk@gmail.com
}

The aim of the work. Studying the influence of the amounts of auxiliary substances on the pharmaco-technological properties of natural zeolite tablets (clinoptilolite) and to optimize the composition of the finished dosage form.

ISSN 2312-0967. Pharmaceutical review. 2018. № 2 
Фармацевтична технологія, біофармація, гомеопатія

Pharmaceutical technology, biopharmacy, homeopathy

Materials and Methods. The objects of research were natural zeolite (tablets of average weight $0.55 \mathrm{~g}$ and diameter of $10 \mathrm{~mm}$, obtained by pressing with pre-wet granulation. In the studies natural zeolite (clinoptilolite) of Sokirnitsky deposit (Zakarpattia region, Ukraine) was used. To select the pharmaceutical factors that significantly affect the object of the study, a full factor experiment $2^{3}$ was used with equal duplication of experiments. Three quantitative factors were studied, the relationship between the factors and the pharmaco-technological parameters of the tablets was expressed and interpreted using regression equations. The experiments used modern equipment. For tests used the methods of the State Pharmacopoeia of Ukraine.

Results and Discussion. According to the data obtained, it was found that the homogeneity of the weight of the tablets is most affected by the concentration of the moisturizer, the mechanical resistance to crushing - by the concentration of the filler, the resistance to abrasion - by the content of the mixture of lactose monohydrate with MCC-101 and potato starch, and at the disintegration time - by the content of potato starch. With the help of regression analysis and additional research according to the "steep climb" scheme, an optimal composition of natural zeolite tablets (clinoptilolite) was established: natural zeolite (clinoptilolite) - 0.4 g; mixtures of lactose monohydrate with MCC-101 (1:1) - 0.085 g; potato starch - 0,047 $\mathrm{g} ; 7 \%$ starch potato paste $-0.1 \mathrm{~g}(0.007 \mathrm{~g}$ of dry); calcium stearate $-0.003 \mathrm{~g}$.

Conclusion. The research was carried out on the selection of quantitative content of auxiliary substances for obtaining zeolite tablets by natural pressing with pre-wet granulation, and the optimal composition of the tablets was proposed, the properties of which correspond to the current requirements of the StPh.

Key words: natural zeolite; clinoptilolite; tablets; excipients; wet granulation; quantitative factors.

\section{Список літератури}

1. Геращенко І. І. Ентеросорбенти: лікарські засоби і дієтичні добавки / І. І. Геращенко. - Київ : НАН України, 2014. - C. 32;

2. Panfilova V. N. Application of enterosorbents in clinical practice / V. N. Panfilova, T. E. Taranushenko // Pediatric Pharmacology. - 2012. - Vol.9, No. 6. - P. 34-39.

3. Artevenko P. D. Modern medical and biological problems of the use of mineral and organic enterosorbents as components of biologically active food additives / P. D. Artevenko, A. V. Posokhova, G. A. Tarasenko // Pacific Medical Journal. - 2009. - No. 1. - P. 29-32.

4. Current challenges in clay minerals for drug delivery / C. Viseras, P. Cerezo, R. Sanchez [et al.] // Appl. Clay Sci. - 2010. - No. 48. - P. 291-295.

5. Carretero M. I. Clay and non-clay mineral sin the pharmaceutical industry part I. Excipients and medical applications / M. I. Carretero, M. Pozo. // Appl. Clay Sci. - 2009. - No. 46. - P. 73-80.

6. Carretero M. I. Clay and non-clay minerals in the pharmaceutical and cosmetic industries part II. Active ingredients / M. I. Carretero, M. Pozo. // Appl. Clay Sci. - 2010. - No. 47. - P. 171-181.

\section{References}

1. Gerashchenko II. Enterosorbents: Drugs and dietary supplements [Ентеросорбенти: лікарські засоби і дієтичні добавки] Kyiv: NAS of Ukraine, 2014. Ukrainian.

2. Panfilova VN, Taranushenko TE. Application of enterosorbents in clinical practice. Pediatric Pharmacology. 2012;9(6): 34-9.

3. Artevenko PD, Posokhova AV, Tarasenko GA. Modern medical and biological problems of the use of mineral and organic enterosorbents as components of biologically active food additives. Pacific Medical Journal. 2009;1: 29-32.
7. Рибачук В. Д. Цеоліти природні / В. Д. Рибачук, Д. В. Рибачук // Фармацевтична енциклопедія. - Вид. 3-е, доп. - Київ : Моріон, 2016. - С. 1871.

8. Рыбачук В. Д. Экспериментальная оценка свойств цеолита природного с позиции его соответствия требованиям для энтеросорбентов / В. Д. Рыбачук // Рецепт. - 2016. - № 6. - С. 668-674.

9. Державна Фармакопея України : у 3-х т. Т. 1 / Державне підприємство «Науково-експертний фрармакопейний центр». - Харків : Державне підприємство «Науковоекспертний фрармакопейний центр», 2015. - 1128 с.

10. Математичне планування експерименту при проведенні наукових досліджень у срармації / [Т. А. Грошовий, В. П. Марценюк, Л. І. Кучеренко та ін.]. Тернопіль : Укрмедкнига, 2008. - 368 с.

11. Рыбачук В. Д. Вивчення кінетики утворення гранул цеоліту природного при різних способах гранулювання [Текст] / В. Д. Рыбачук // Annals of Mechnikov Institute. 2016. - N 4. - С. 88-96.

12. Рыбачук В. Д. Изучение технологических свойств гранул цеолита природного / В. Д. Рыбачук // "VESTNIK" of the South-Kazakhstan state pharmaceutical academy. 2015. - № 4. - C. 108-110.

4. Viseras C, Cerezo P, Sanchez R, Salcedo I, Aguzzi C. Current challenges in clay minerals for drug delivery. Appl. Clay Sci. 2010;48: 291-5.

5. Carretero MI, Pozo M. Clay and non-clay mineral sin the pharmaceutical industry part I. Excipients and medical applications. Appl. Clay Sci. 2009;46: 73-80.

6. Carretero MI, Pozo M. Clay and non-clay minerals in the pharmaceutical and cosmetic industries part II. Active ingredients. Appl. Clay Sci. 2010;47: 171-181.

7. Rybachuk VD, Rybachuk DV [Natural zeolites] Phar-

ISSN 2312-0967. Фармацевтичний часопис. 2018. № 2 
Фармацевтична технологія, біофармація, гомеопатія

Pharmaceutical technology, biopharmacy, homeopathy

maceutical Encyclopedia: 3rd Edition [Фармацевтична енциклопедія: вид. 3-тє]. Kyiv: "Morion"; 2014. Ukrainian. 8. Rybachuk VD [Experimental assessment of properties of natural zeolite from the point of its conformity to requirements to enterosorbents]. «Recipe». 2016;6: 668-74. Russian.

9. The State Pharmacopoeia of Ukraine: in 3 Volumes [Державна фрармакопея України]. Kharkiv: State Enterprise "Scientific and Expert pharmacopoeia Centre", 2015. - Volume 1. Ukrainian.
10. Hroshovyi TA, Martsenyuk VP, Kucherenko LI, Vronska LV, Huryeyeva CM. Mathematical planning of experiment in pharmacy. [Математичне планування експерименту в фрармації] Ternopil: Ternopil State Medical University; 2008. Ukrainian.

11. Rybachuk VD [The study of the kinetic of natural zeolite granules growth at different ways of granulation]. Annals of Mechnikov Institute.2016; 4: 88-96. Ukrainian.

12. Rybachuk VD [Study of the technological properties of natural zeolite granules] "VESTNIK" of the South-Kazakhstan State Pharmaceutical Academy. 2015;4: 108-10.

Отримано 05.02.2018 